\title{
Human papillomavirus E5 protein, the undercover culprit of tumorigenesis
}

Nima Hemmat ${ }^{1,2}$ and Hossein Bannazadeh Baghi ${ }^{1,3,4^{*}}$ (D)

\begin{abstract}
Human papillomavirus (HPV) is the most common viral infection of the reproductive tract worldwide. It has been well documented that the HPV oncoproteins E6 and E7 play important roles in cancer progression and maintenance. However, the high risk HPV E5 protein is also demonstrated to affect some cellular pathway and signaling in human cell lines. In this letter we argue for the need of further investigation and suggest that the HPV E5 protein should be acknowledged as an oncoprotein of HPV.
\end{abstract}

Keywords: HPV, Cervical cancer, HPV E5 protein, Tumorigenesis

\section{Letter to the editor}

Dear Editor,

Human papillomavirus (HPV) has been proven to be the main cause of cervical cancer worldwide [1]. Most studies, about HPV tumorgenesis, focus on the role that high risk HPV E6, and E7 proteins play [2]. However high risk HPV E5 protein, one of the virus early phase proteins, is demonstrated to have an important effect on cellular and signaling pathways in human cell lines [3]. Many functions have been described for this viral protein, including, cell transforming activity (Fig. 1), influencing cell cycle and growth factors, induction of apoptosis and endoplasmic reticulum (ER) stress, and immune evasion [3]. HPV E5, as a cell transformer, can interact with the $16 \mathrm{KDal}$ subunit of vacuolar-ATPase (V-ATPase) and disrupt acidification of endosomes [4]. This phenomenon enhances epidermal growth factor (EGF) receptor recycling [4]. Additionally, it has been indicated that the E5 protein increases the expression level of Met, a hepatocyte growth factor (HGF) receptor, promoting transformed cell invasiveness [5]. E5 is also shown to be bonded with an A4 protein, a transmembrane lipoprotein of the endoplasmic reticulum, thus regulating proliferation of infected cells [6]. With all of this considered, it is highly suggested that the HPV E5 protein should be acknowledged as an oncoprotein of HPV. Especially, for the production of DNA-based vaccines this can be of utmost importance. As HPV infections are spread more widely around the world [7], also affecting areas that were thought to be protected by it due to more conservative sexual conduct [8], DNA-based vaccines against HPV should contain not only HPV E6 and E7 coding genes [9], but also E5. Novel vaccines could be used therapeutically as well as in a preventive way. Currently, dispensed vaccines are based on the HPV L1 capsid protein and are able to induce protective immunity (by production of memory cells against $\mathrm{L} 1)$.

\footnotetext{
* Correspondence: hbannazadeh@tbzmed.ac.ir; hb.zadeh@gmail.com ${ }^{1}$ Immunology Research Center, Tabriz University of Medical Sciences, Tabriz, Iran

${ }^{3}$ Infectious and Tropical Diseases Research Center, Tabriz University of Medical Sciences, PO Box 5165665931, Tabriz, Iran

Full list of author information is available at the end of the article
} 


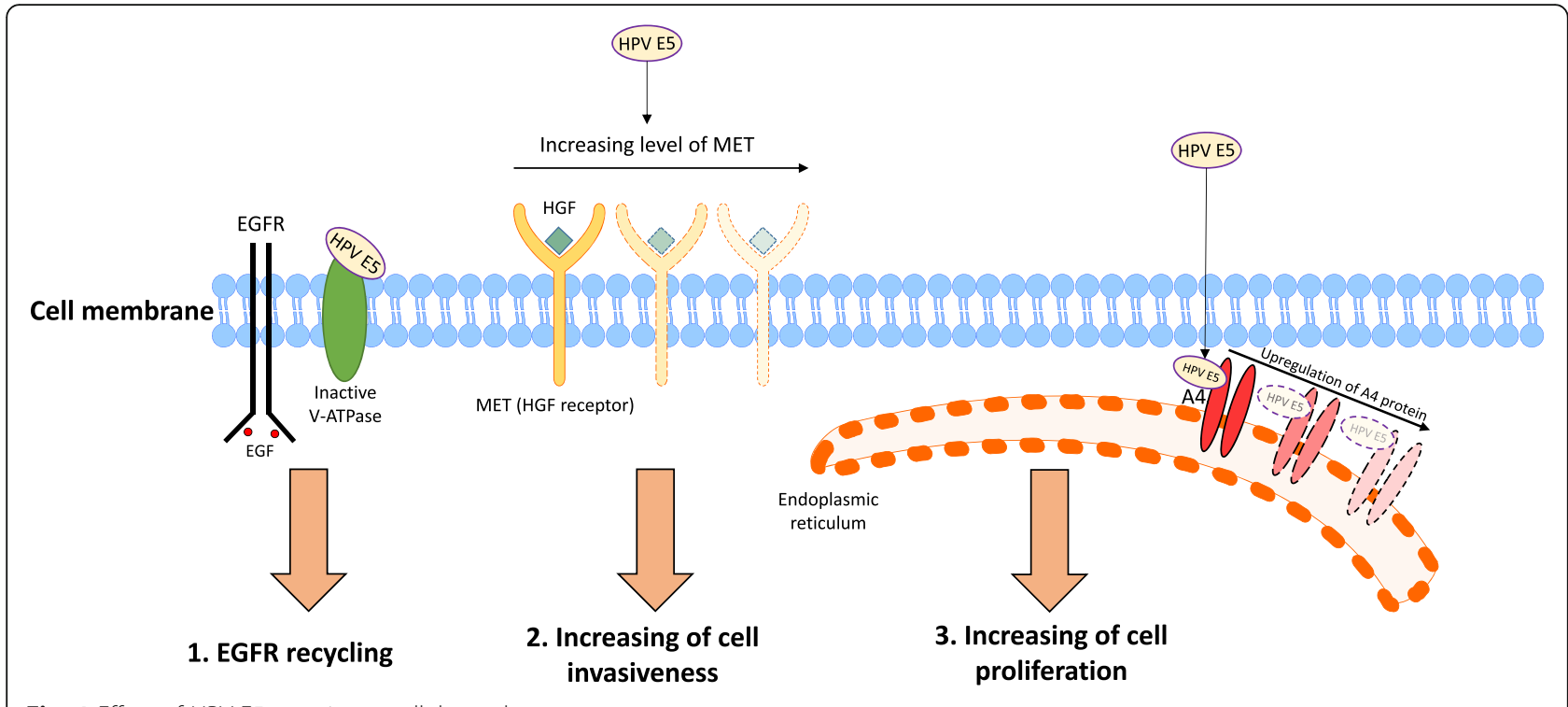

Fig. 1 Effect of HPV E5 protein on cellular pathways

\section{Abbreviations}

EGF: Epidermal growth factor; ER: Endoplasmic reticulum; HGF: Hepatocyte growth factor; HPV: Human papillomavirus; V-ATPase: Vacuolar-ATPase

\section{Acknowledgements}

Not applicable.

\section{Funding}

Not applicable.

\section{Availability of data and materials}

Not applicable.

\section{Authors' contributions}

Both authors contributed towards the design and writing of the article. Both authors have read and approved the final version.

\section{Ethics approval and consent to participate}

Not applicable.

\section{Consent for publication}

Not applicable.

\section{Competing interests}

The authors declare that they have no competing interests.

\section{Publisher's Note}

Springer Nature remains neutral with regard to jurisdictional claims in published maps and institutional affiliations.

\section{Author details}

${ }^{1}$ Immunology Research Center, Tabriz University of Medical Sciences, Tabriz, Iran. ${ }^{2}$ Drug Applied Research Centre, Tabriz University of Medical Sciences, Tabriz, Iran. ${ }^{3}$ Infectious and Tropical Diseases Research Center, Tabriz University of Medical Sciences, PO Box 5165665931, Tabriz, Iran. ${ }^{4}$ Department of Microbiology Faculty of Medicine, Tabriz University of Medical Sciences, Tabriz, Iran.
Received: 2 August 2018 Accepted: 31 October 2018

Published online: 09 November 2018

\section{References}

1. Wakeham K, Kavanagh K. The burden of HPV-associated anogenital cancers. Curr Oncol Rep. 2014;16(9):402.

2. Ganguly N, Parihar SP. Human papillomavirus E6 and E7 oncoproteins as risk factors for tumorigenesis. J Biosci. 2009;34(1):113-23.

3. Venuti A, Paolini F, Nasir L, Corteggio A, Roperto S, Campo MS, et al. Papillomavirus E5: the smallest oncoprotein with many functions. Mol Cancer. 2011;10(1):140.

4. Kim M-K, Kim HS, Kim S-H, Oh J-M, Han JY, Lim JM, et al. Human papillomavirus type 16 E5 oncoprotein as a new target for cervical cancer treatment. Biochem Pharmacol. 2010:80(12):1930-5.

5. Scott ML, Coleman DT, Kelly KC, Carroll JL, Woodby B, Songock WK, et al. Human papillomavirus type 16 E5-mediated upregulation of met in human keratinocytes. Virology. 2018:519:1-11.

6. Halavaty KK, Regan J, Mehta K, Laimins L. Human papillomavirus E5 oncoproteins bind the A4 endoplasmic reticulum protein to regulate proliferative ability upon differentiation. Virology. 2014:452:223-30.

7. Baseman JG, Koutsky LA. The epidemiology of human papillomavirus infections. J Clin Virol. 2005:32:16-24.

8. Baghi HB, Yousefi B, Oskouee MA, Aghazadeh M. HPV vaccinations: a middle eastern and north African dilemma. Lancet Infect Dis. 2017:17:18-9.

9. Ahn J, Peng S, Hung CF, Roden R, Wu TC, Best SR. Immunologic responses to a novel DNA vaccine targeting human papillomavirus-11 E6E7. Laryngoscope. 2017;127(12):2713-20.

Ready to submit your research? Choose BMC and benefit from:

- fast, convenient online submission

- thorough peer review by experienced researchers in your field

- rapid publication on acceptance

- support for research data, including large and complex data types

- gold Open Access which fosters wider collaboration and increased citations

- maximum visibility for your research: over $100 \mathrm{M}$ website views per year

At BMC, research is always in progress.

Learn more biomedcentral.com/submission 